\title{
Design of an educational strategy for environmental school programs in Colombia
}

\author{
Diseño de una estrategia educativa para Programas Ambientales Escolares en \\ Colombia
}

\author{
C.F. Valderrama-López iD ; J.D. . Ortiz-Avilés iD; M. M. Usa-Peña iD; O. L. Fierro iD \\ DOI: https://doi.org/10.22517/23447214.22261 \\ Artículo de investigación científica y tecnológica
}

\begin{abstract}
There is a problem associated with the impact generated by environmental education in Latin American educational institutions and how it is reflected in the behaviour of students and its contribution to society. This research proposes the design of a sustainable strategy to develop Environmental Programs in Educational Institutions. The research was carried out in the city of Neiva - Colombia. A sample of 34 institutions was used, and an interview was conducted with three schools that reported successful environmental projects at a national level. It was found that by 2018 only $9 \%$ of educational institutions had successfully developed School Environmental Programs, 93\% state that the availability of time is one of the biggest obstacles for its implementation, and $67 \%$ of these ensure that they have not received technical advice nor have the necessary financial resources.
\end{abstract}

Index Terms - Academic culture, Community problems, Environmental Awareness, Environmental education, Sustainable development.

Resumen - Existe una problemática asociada al impacto que está generando en la educación ambiental en las instituciones educativas latinoamericanas $y$ como esta se refleja en el comportamiento de los estudiantes y en el aporte a la sociedad. La presente investigación propone el diseño de una estrategia de sostenibilidad para los Programa Ambientales en Instituciones Educativas. La investigación se desarrolló en la ciudad de Neiva Colombia. Se utilizó una muestra de 34 instituciones y se realizó una entrevista a 3 colegios que reportaron proyectos ambientales exitosos a nivel nacional pertenecientes a este territorio. Se encontró que para el año 2018 solo el $9 \%$ de las instituciones educativas han logrado volver exitoso un Programa Ambiental Escolar, el 93\% afirman que la disponibilidad de tiempo es uno de los mayores obstáculos para su implementación y el $67 \%$ de estas aseguran no haber recibido asesoría técnica, ni contar con los recursos económicos necesarios.

Este manuscrito fue enviado el 11 de agosto de 2019 y aceptado 23 de noviembre 2020.

C.F. Valderrama-López, Profesor Universidad Nacional Abierta y a Distancia, Investigador grupo COBIDES, Neiva, Colombia. (e/mail: christian.valderrama@unad.edu.co)

J. Ortiz Avilés, Ingeniero Ambiental, Universidad Nacional Abierta y a Distancia, Neiva, Colombia. (JDORTIZAV@unadvirtual.edu.co)
Palabras clave- Cultura académica, Desarrollo sostenible, Educación ambiental, Problemas locales, Sensibilización ambiental.

Resumo - Existe um problema associado ao impacto que está gerando na educação ambiental as instituições de ensino latinoamericanas e como isso se reflete no comportamento dos alunos e em sua contribuição na sociedade. Esta pesquisa propõe o desenho de uma estratégia sustentável para o desenvolvimento de Projetos Ambientais Escolares (PRAE) em instituições de ensino. A pesquisa foi realizada na cidade de Neiva - Colômbia. No estudo foi utilizada uma amostra de 34 instituições e foi realizada uma entrevista com três escolas que relataram projetos ambientais bem sucedidos no nível nacional. Se verificou que em 2018, apenas 9\% das instituições de ensino tinham desenvolvido com sucesso os Projetos Ambientais Escolares, 93\% mencionaram que a disponibilidade de tempo é um dos maiores obstáculos para sua implementação e $67 \%$ das instituições afirmaram que não receberam apoio técnico nem dispõem dos recursos financeiros necessários.

Palavrasclaves-Cultura Acadêmica, Consciência Ambiental, Desenvolvimento Sustentável, Educação Ambiental, Problemas Locais.

\section{INTRODUCTION}

$\mathrm{E}$ NVIRONMENTAL Education (EE hereafter) arises as a response to the growing global environmental crisis [1], and it is one of the greatest tools to minimize the negative impacts caused by humans on the environment [2]. In the case of Colombia, EE is stipulated as mandatory in all educational institutions without exception, so that from an early age students can develop an adequate relationship with their environment [3]. EE aims to teach students to preserve their natural environment with sustainable progress as a baseline, as well as being aware of the interaction between other socioenvironmental problems that manifest as side effects. However, EE is not exclusive from the educational institutions [4]; it must

M. M. Usa-Peña, Ingeniera Ambiental, Universidad Nacional Abierta y a Distancia, Neiva, Colombia. (mmusap@unadvirtual.edu.co)

O. L. Fierro, Licenciada en Educación Básica con Énfasis en Humanidades, especialista en docencia universitaria, Magister en didáctica en inglés. (olga.fierro@unad.edu.co). 
be a commitment from the whole society. In consequence, it is necessary to propose the appropriate solutions and create alternatives that diminish the negative impacts that have occurred throughout history and that are currently a major global issue.

School is seen as the entity that offers an important indicator in the instruction of individuals for the teaching of mechanisms in defence of the environment [5], the proper use of resources and their conservation [6]. It is fundamental to address EE from school, taking care of possible reductionisms, determinism, and fragmentations [7]. Moreover, EE must transcend and seek an appropriation and transfiguration of reality with the support of research, which is a challenge in the educational communities [8].

Although there have been great advances in EE, it has not been well received, which raises new challenges mainly for school [9] to solve certain barriers that emerge [10]; [11]. Facing those difficulties depends on the few research processes that arise from different disciplines [11]. From a didactic scope, EE development is sometimes not adequate, resulting in generalities in which its impact is reduced to the area of natural sciences (Gutiérrez, 2002; [13]. Thus, there is a need in the field of EE to support and promote more focused research in the region, centered on the creation and articulation of associations between professionals and academics that allows a generation of results according to the needs of the communities (Briggs, Trautmann, \& Fournier, 2018).

This research sought to determine the factors that influence the implementation of Environmental School Projects (PRAE, by its acronym in Spanish) in the educational institutions within the urban area of Neiva. Its purpose was to contribute to the strengthening of EE in schools by designing a strategy that allows approaching the reality through active participation, focused in the resolution of local problems, assuming a commitment and proposing innovative solutions.

\section{METHODS}

This research project was carried out with the support of the public and private educational institutions from the urban area of the municipality of Neiva in Colombia. It was developed in four stages:

1. Data gathering: We identified the educational institutions (public and private) that offered the three levels of formal education: preschool, primary school and high school in Neiva.

2. We took a simple random sample of 50 educational institutions that offered the three levels of formal education: preschool, primary school and high school. According to 1 and 2 .

$$
n_{\circ}=\frac{Z^{2} p q}{e^{2}} \quad n^{\prime}=\frac{n_{\circ}}{1+\left(\frac{n_{\circ}-1}{N}\right)}
$$

Where:

$\mathrm{n}=$ initial sample size

$\mathrm{Z}=1.96$

$\mathrm{q}=0.5$

$\mathrm{e}=8 \%$

$\mathrm{p}=0.5$

$\mathrm{N}=50$

With this data we obtained $n=34$ educational institutions. We started analyzing the data.

3. We designed and applied a Likert rating scale instrument to collect information from the initial educational institutions sample. This instrument was divided in three parts. The first one analyzed the EE in general terms, the second one focused on the reasons why they have not implemented PRAE, and the last part analyzed the results regarding the process of implementation of this type of projects.

4. We designed and carried an interview with three educational institutions that have excelled in the region with their EE experiences.

\section{RESULTS AND DISCUSSION}

By analyzing the data collected through the survey, we tried to identify the factors that influence the design and development of PRAE in 34 educational institutions in Neiva. $91 \%$ out of these 34 institutions develop a PRAE while the other $9 \%$ has not been able to implement one yet.

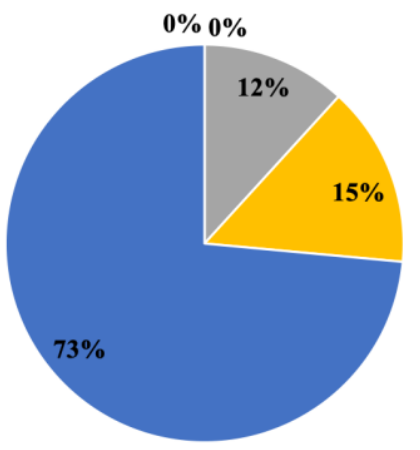

- Not at all important

= Not important

- Slightly important

$=$ Important

- Very important

Fig 1. Importance of Environmental Education, 2019.

Fig. 1 shows that $73 \%$ of the educational institutions consider EE important. They define EE as a tool that shapes values and behaviors in students to face the current environmental crisis that poses great challenges for the modern society [1]. 


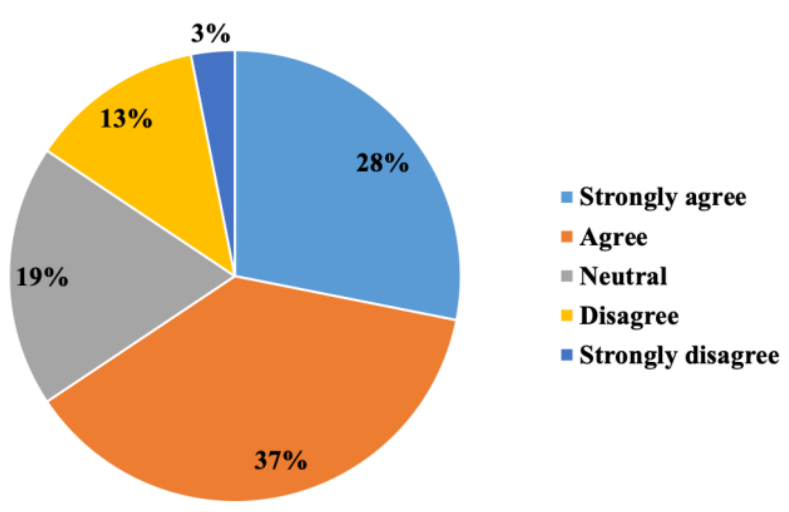

Fig 2. Environmental Education in school, 2019.

Fig 2 shows that $20 \%$ of the educational institutions considered that their current EE is excellent, $35 \%$ considered their $\mathrm{EE}$ above average and $19 \%$ assured that their $\mathrm{EE}$ is satisfactory. Likewise, $13 \%$ barely gave EE classes and the other 3\% said that they hardly ever had EE classes.

Moreover, we found that $91 \%$ of the schoolteachers considered that it is necessary to tackle social issues and relate them to environmental issues, with the purpose of working integrally to obtain positive results for the community.

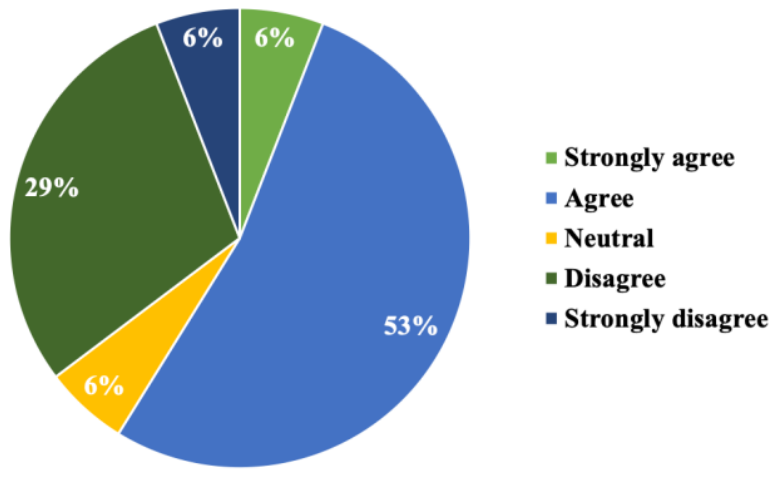

Fig 3. Perspective of Environmental Education at school, 2019.

It can be observed in Fig. 3 that although EE presents significant advances at an international level and especially at the national level, the expected impact has not been achieved yet [14]. This is something noticed by most of the school teachers from the 34 educational institutions visited, as 59\% of them assured that EE in the schools is something that currently has little impact and that there are still behaviors and inadequate practices in most parts of the society.

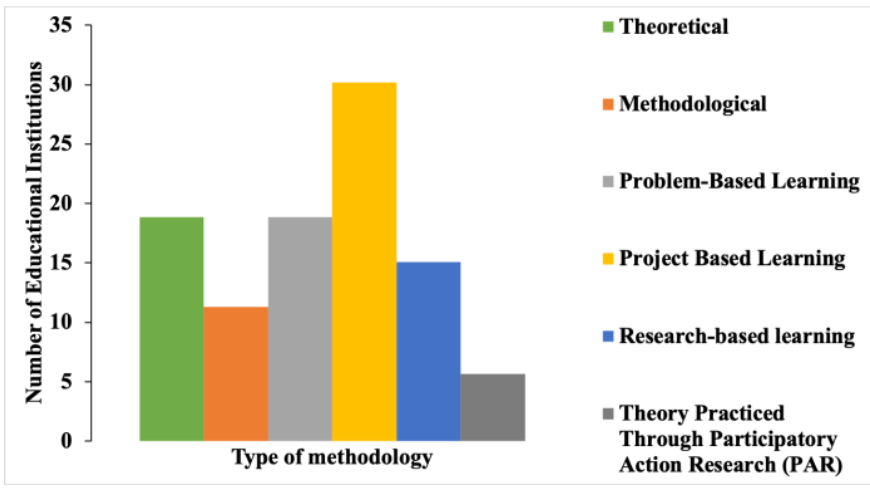

Fig 4. Methodologies used for environmental education at school, 2019.

Fig. 4 shows that $47 \%$ of the educational institutions use Project-Based Learning methodology, followed by Problem Based Learning with 29\%. From the above it can be highlighted that these methodologies are considered very important because they allow creating an environment of cooperation and participation, where the student is an active problem solver, that becomes a researcher and participant in the decision-making guided by the teacher [15], generating greater interest and productivity for the activities carried out.

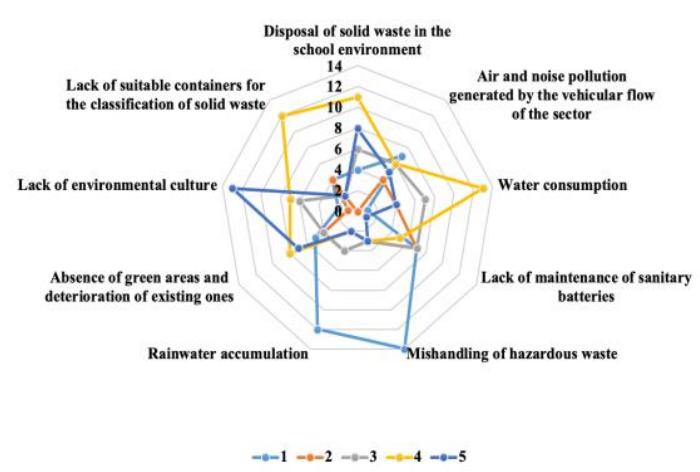

Fig 5. Current environmental issues at the educational institutions, 2019.

According to the report given by the teachers in the Fig. 5, the topics associated with the handling of hazardous waste, the accumulation of rainwater, the lack of environmental culture, the non-rationalization of water resources usage, the lack of containers and the inadequate waste disposal are the most common problems that the 34 institutions have. It is noteworthy that the vast majority of these problems can be managed or mitigated through the design of an Environmental Management System [16], which will identify critical points, inventory waste, and resources, and optimize their use. 


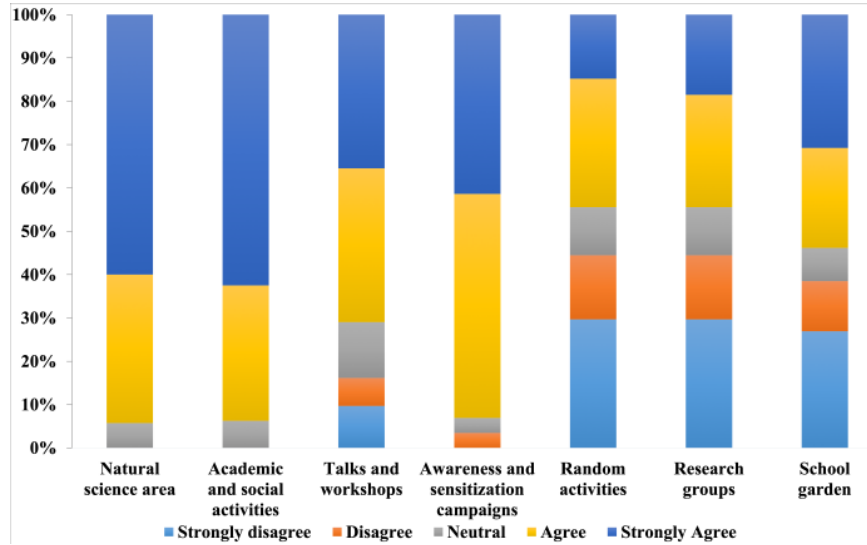

Fig 6. Development of EE in the educational institutions, 2019.

According to Fig. 6, in the educational institutions, EE is being addressed primarily through the area of natural sciences (95\%), followed by academic activities associated with social work (94\%), awareness and sensitization campaigns (73\%), and specific talks or workshops.

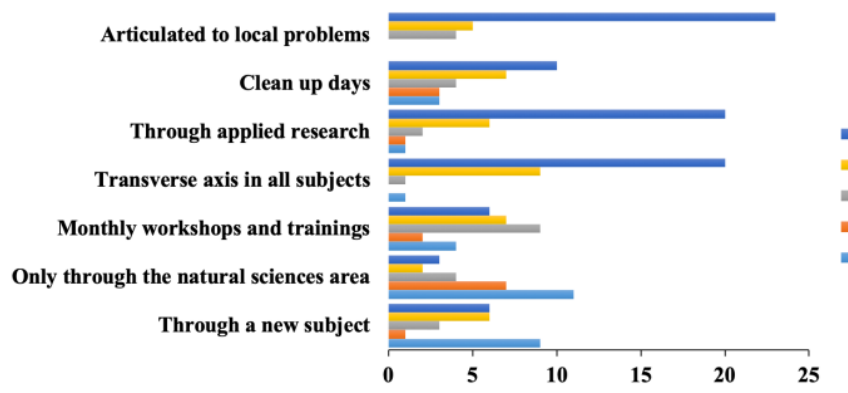

Fig 7. Best method for teaching EE, 2019.

Fig. 7 shows that $68 \%$ of teachers consider that the best way to approach EE is through its articulation with local problems; $58 \%$ think that this should be done through applied research. Applied research is a fundamental part of the training processes [17] since it contributes to reflection and self-questioning when it comes to providing solutions to local environmental problems and strengthening the attitudes and skills of students in decision-making. Moreover, it is not coherent nor logical to talk about the environment without disclosing the reality from the local context.

Likewise, $58 \%$ of the teachers consider that EE should be a transversal axis in all subjects. This opinion agrees with Velásquez (2009) since he believes that this topic permeates the entire curriculum and should become an institutional policy. Finally, we found that $32 \%$ of the educational institutions mentioned that EE is approached from the area of natural sciences, becoming in some cases the only subject or the most committed to the issue [9].

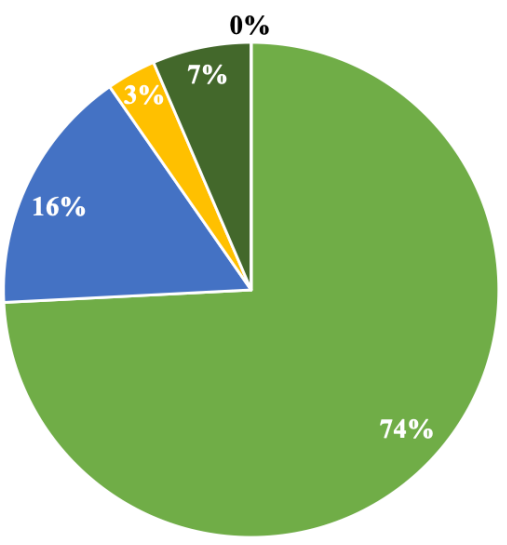

\section{- Always - Almost Always " Normally - Sometimes " Never}

Fig 8. Importance of PRAE to develop environmental culture, 2019.

According to Fig. 8, 74\% of the educational institutions assure that the PRAE is very important for the promotion of environmental culture, $16 \%$ almost always promote the projects, 3\% usually do it and 7\% sometimes have it carried out. The aforementioned allows interpreting that teachers consider 4 PRAE an important tool for the formation of an environmental culture, that starts from school and goes beyond a requirement or compliance [18]. Likewise, Triff [19] argue that certain erroneous differences on the conceptions and teaching practices of EE are transmitted to the students, resulting in specific approaches that, instead of contributing, harm the formation of environmental culture.

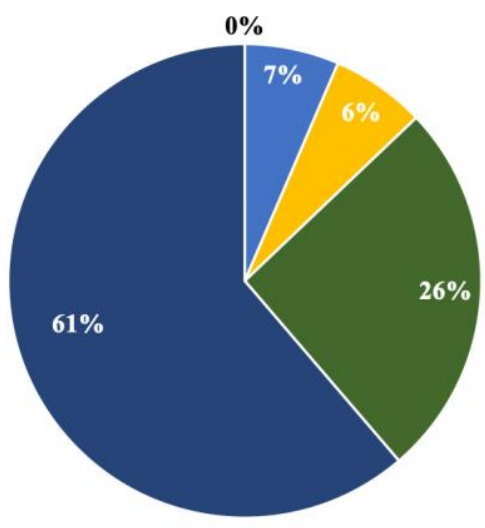

"Strongly disagree $=$ Disagree $=$ Neutral $=$ Agree $\|$ Strongly agree

Fig 9. Importance of PRAE according to the teachers, 2019.

Fig. 9, shows that from the 34 institutions and educational centers surveyed, $61 \%$ agree that PRAE are very important, and $26 \%$ think they are significantly important, which presents certain shortcomings and associated disadvantages to effectiveness, very similar to what Vilches [20] proposes, regarding the little impact caused by the projects against the power, the big industry, and the indifferent society. 


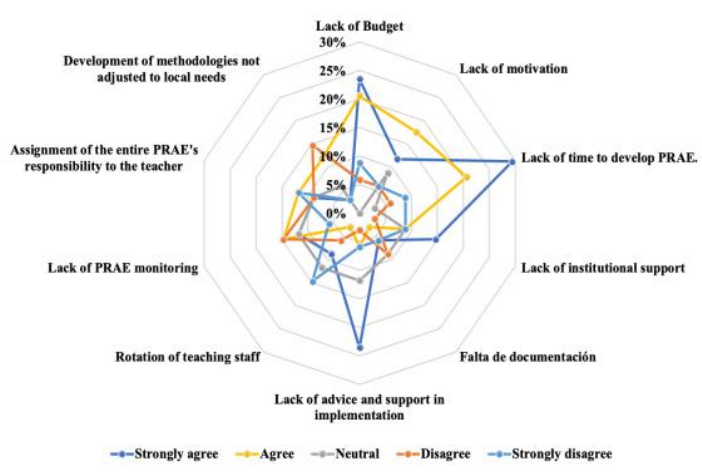

Fig 10. Factors of unsustainability of PRAE, 2019.

According to the network diagram in Fig. 10, 30\% of the population mentioned that the lack of time to develop PRAE is one of the most critical factors. Consistent with Penwell [21], this barrier is considered to be the most significant as almost all institutions reported it. Moreover, 24\% considered that the lack of budget is fundamental since this factor generates and is directly related to the sustainability of the projects [11].

Finally, as reported by $24 \%$ of the institutions, the lack of consulting and accompaniment from the concerned state entities is also a reason that influences the sustainability of the projects.

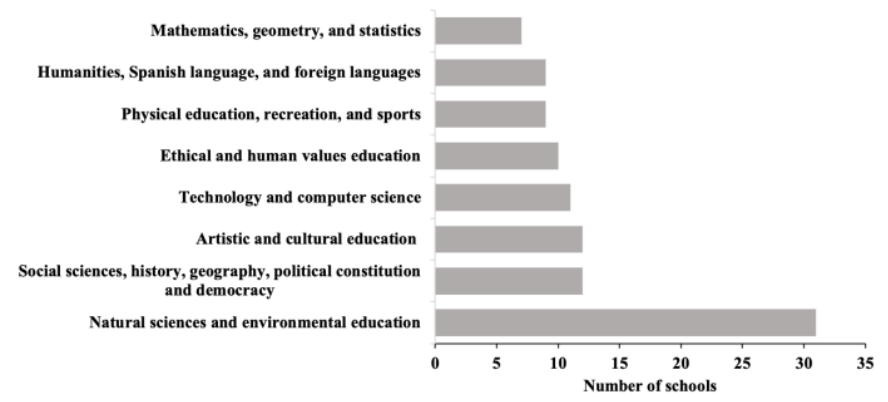

Fig 11. Subjects that participate in the development of PRAE, 2019.

Fig. 11 shows that the subjects of most significant participation in the different PRAE activities within the educational institutions are: natural sciences and environmental education with a $91 \%$ rating, followed by both social sciences and history, geography, political constitution and democracy, and artistic and cultural education with $39 \%$. Moreover, technology and computer science rated 35\%; after that, ethical and human values education obtained $32 \%$, physical education, recreation, and sports rated 29\% and religious education 23\%; humanities, Spanish language, and foreign languages rated $29 \%$ while mathematics, geometry, and statistics rated $23 \%$.

Three interviews were carried out with educational institutions that have been awarded by the environmental entity for the design, contents, and execution of their PRAE. We used ATLAS.ti software to make the qualitative analysis supported by semantic networks, as shown in Fig. 12 and Fig. 13.

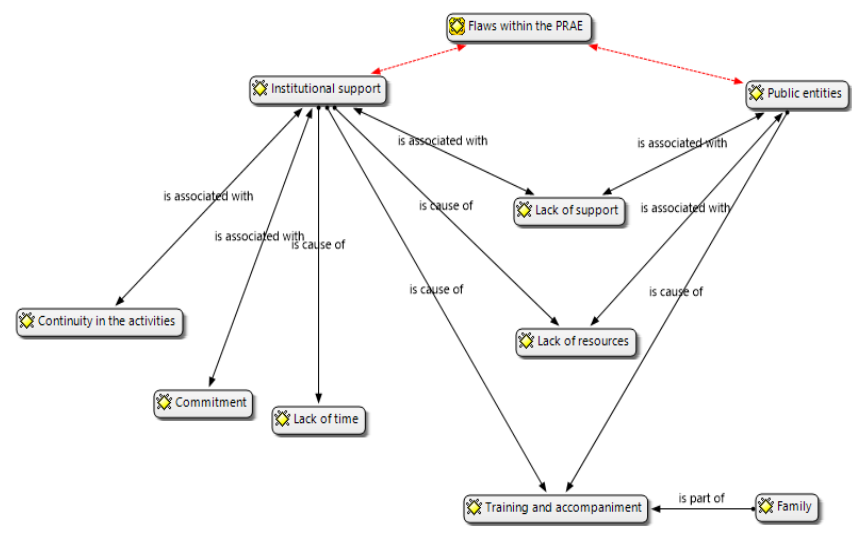

Fig 12. Flaws within the PRAE, 2019.

As a result of this process, we found that the teachers highlight two critical flaws within the PRAE in educational institutions, which end up being the cause of the non-implementation or failures of this tool in schools. The first of these is the lack of institutional support. A tool that is not supported by the stakeholders will not generate a great impact as no time is allocated to the teacher nor resources assigned or managed, and the activities are developed with little or no involvement of the students' families. Moreover, the disarticulation between public entities and the education sector is causing them not to provide the correct technical and financial support for the implementation of these projects, which generates documents that do not have an impact in the local or familiar environment.

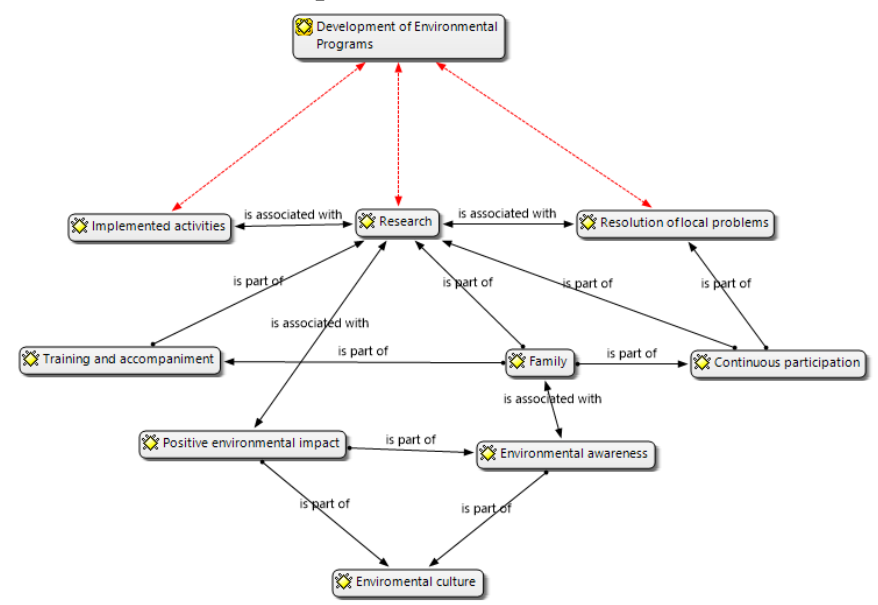

Fig 13. Experiences for the correct development of PRAE, 2019.

Teachers emphasized that for a PRAE to develop correctly, it must start from 3 fundamental axes that are directly related: research, resolution of local problems, and applied practice activities. These axes must be developed continuously and accompanied, and it should involve families so that it generates environmental awareness both in the students and in their families, as well as a positive environmental impact that will lead to the formation of environmental culture in the educational and local environment. 


\section{Educational Strategy Designed From A Model Based ON EXPERIENCES}

From the data gathered in the educational institutions and the successful experiences in the development of PRAE, it is evident that PRAE becomes significant or that it generates positive impact in the institutions when it is based on research processes. However, this can be complex for the teachers as it implies working overtime, as well as a demanding reading and writing exercise in line with the specific field of research [22]. Furthermore, when PRAE is interactive and encourages and

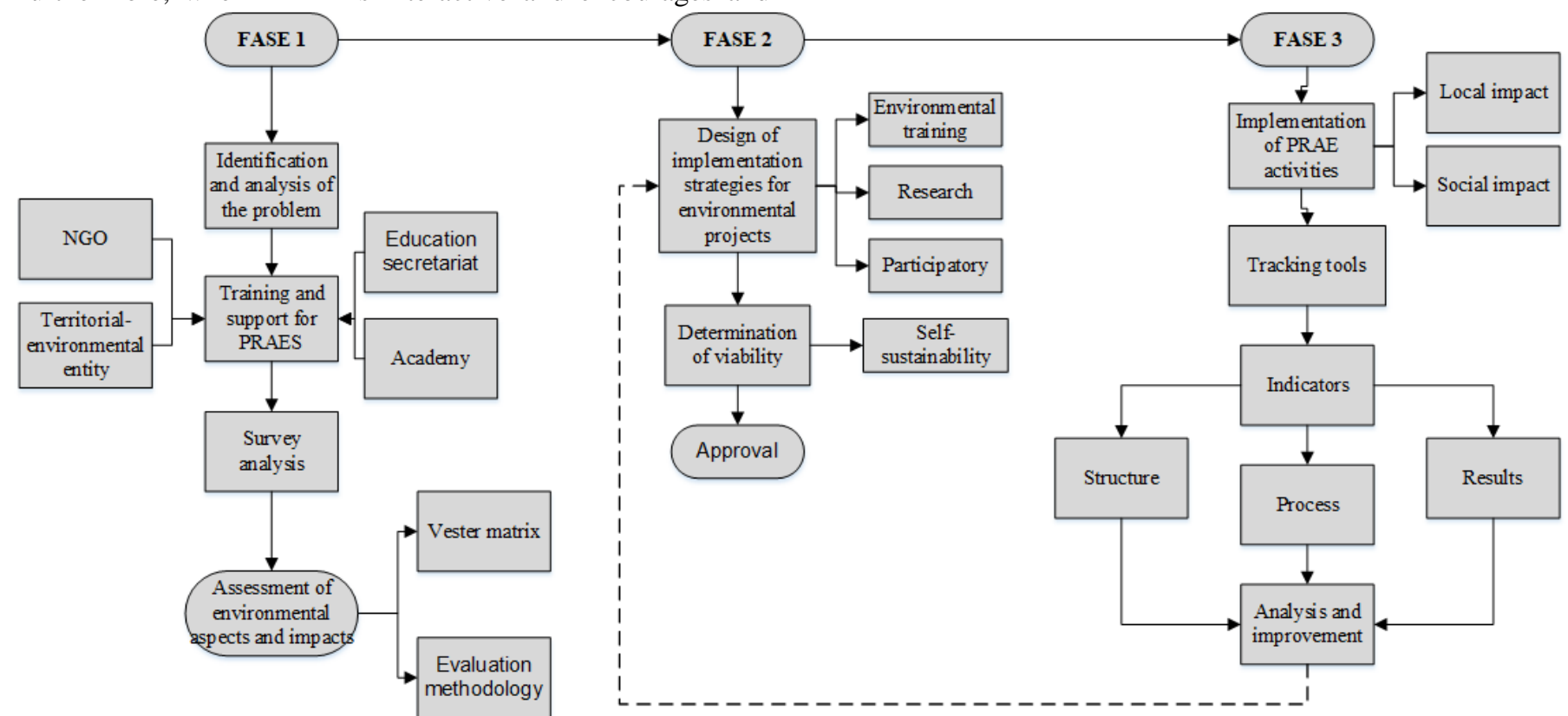

Fig 14. Methodological model restructured to elaborate a

PRAE, adapted from the compliance management plan of PRAE in educational institutions from the rural area from the municipality of Magdalena. 2016. By Gonzalez, H., 2016. Adapted by Usa M., Ortiz J \& Valderrama C. 2019.

Based on the information previously described, and the methodological model to implement PRAE in Colombia [23], we designed a proposal to restructure it, so that it does not only include the processes to follow, but that shows certain key aspects that should be considered to contribute to the proper formulation, execution, and implementation of the projects. Fig. 14 shows the design that consists of 3 phases that require a continuous interaction between the educational institution, the university, the companies, and the state, leveraging participatory and research structures with indicators that allow measuring the progress from the structure, the process, and the results, and that is adjusted to a model of continuous improvement.

\section{CONCLUSIONES}

Through this research, we determined the factors that influence the formulation and implementation of environmental programs in educational institutions. The two most critical scenarios are motivates those involved through practical activities, it can raise awareness and build an environmentally conscious attitude, although care must be taken not to fall into activism or reductionism [9]. Moreover, institutional support is essential so that, through the entire teaching team, articulated results with a high social impact can be achieved. the lack of institutional support and the lack of state support as they trigger problems associated with the lack of time allocated to teachers, the lack of resources for implementation, and the unawareness of the structure to formulate environmental and social impact strategies for the community.

An example of this is the fact that $91 \%$ out of the 34 educational institutions implement PRAE disconnected from the local environment, and reduced only to the development of pedagogical practices and activities associated with the area of natural sciences.

Structuring PRAE must start from the experiences gathered by the teachers, the community, and the students, as a participative and constructive process. They should preferably be implemented using the proposed model as it allows the integration of research as a fundamental axis in the development of activities and processes. They must be dynamic, practical and focused on solving local problems, so that knowledge can permeate and transcend from the classroom to the families and local environment, as this should be the engine to raise environmental awareness and culture among the communities. 


\section{ACKNOWLEDGMENT}

To the Secretary of Education and the Regional Autonomous Corporation of the Alto Magdalena (CAM) for supplying information from the database of the educational institutions in Neiva, as well as each one of the institutions that collaborated with us and allowed the application of the research instruments such as the survey and the interview.

\section{REFERENCES}

F. Estenssoro Saavedra, "Crisis ambiental y cambio climático en la política global: Un tema crecientemente complejo para américa latina," Universum (Talca), vol. 25, no. 2, pp. 55-57, 2010. https://doi.org/10.4067/s0718-23762010000200005

[2] L. A. Pita-Morales, "Línea de tiempo: educación ambiental en Colombia," Praxis (Bern. 1994)., vol. 12, p. 118, Dec. 2016. http://dx.doi.org/10.21676/23897856.1853

[3] C. R. Santos, N. M. Grilli, N. P. Ghilardi-Lopes, and A. Turra, "A collaborative work process for the development of coastal environmental education activities in a public school in São Sebastião (São Paulo State, Brazil)," Ocean Coast. Manag., vol. 164, pp. 147155, 2018. https://doi.org/10.1016/j.ocecoaman.2017.08.011

[4] C. P. Ariza, L. Á. Rueda, and J. Blanchar, "La educación ambiental como estrategia global para la sustentabilidad," Boletín Redipe, , vol. 6, no. 5, pp. 64-70, 2017.

[5] C. Eames and S. Birdsall, "Teachers' perceptions of a co-constructed tool to enhance their pedagogical content knowledge in environmental education.," Environ. Educ. Res., vol. 25, no. 10, pp. 1438-1453, Oct.

2019. https://doi.org/10.1080/13504622.2019.1645445

F. Cifuentes-Ávila, R. Díaz-Fuentes, and S. Osses-Bustingorry, "Ecología del comportamiento humano: las contradicciones tras el mensaje de crisis ambiental," Acta Bioeth., vol. 24, no. 2, pp. 161165, Dec. 2018. http://dx.doi.org/10.4067/S1726569X2018000200161

[7] R. Valderrama-Hernández, L. Alcántara, and D. Limón, "The Complexity of Environmental Education: Teaching Ideas and Strategies from Teachers," Procedia - Soc. Behav. Sci., vol. 237, pp. 968-974, Feb. 2017. https://doi.org/10.1016/j.sbspro.2017.02.137

[8] J. J. Barba-Martín, G. González-Calvo, and R. Barba-Martín, "Que la fuerza esté contigo: desvelar el lado oscuro de la investigación en educación,” Magis. Rev. Int. Investig. en Educ., vol. 7, no. 14, p. 125, Dec. 2014. https://doi.org/10.11144/Javeriana.M7-14.QLFE

[9] L. H. Gutierrez-Sabogal, "Problemática de la educación ambiental en las instituciones educativas -Problematic of the Environmental Education in Educational Institutions," Rev. Científica, vol. 3, no. 23, p. 57, Jan. 2016. https://doi.org/10.14483/udistrital.jour.RC.2015.23.a5

[10] M. Ketlhoilwe, "Environmental Education Policy Implementation Challenges in Botswana Schools," South. African J. Environ. Educ., vol. 24, no. 0, pp. 171-184-184, 2007.

[11] C. Anderson and S. Jacobson, "Barriers to environmental education: How do teachers' perceptions in rural Ecuador fit into a global analysis?," Environ. Educ. Res., vol. 24, no. 12, pp. 1684-1696, Dec. 2018. https://doi.org/10.1080/13504622.2018.1477120

[12] J. Gutiérrez Pérez, "Grados de libertad y enfoques autóctonos de la investigación en educación ambiental," Investig. en la Esc., no. 46, pp. 27-39, 2002. https://doi.org/10.12795/IE.2002.i46.02

[13] E. García, Educación ambiental, constructivismo y complejidad. Una propuesta integradora., vol. Bernal, Te. Díada Editora, 2004.

[14] "La educación ambiental en Colombia, utopía o realidad | Revista Conrado." [Online]. Available: https://conrado.ucf.edu.cu/index.php/conrado/article/view/949. [Accessed: 16-Mar-2020]

[15] A. Martín and S. Rogríguez, "Motivación en alumnos de Primaria en aulas con metodología basada en proyectos," Rev. Estud. e Investig. en Psicol. y Educ., no. 01, p. 058, Oct. 2015. https://doi.org/10.17979/reipe.2015.0.01.314

[16] P. C. Monroy-Abril, W. F. Castrillón-Cardona, and D. del S. DazaArdila, "Revisión de modelos de gestión ambiental en instituciones de educación superior . Review of environmental management models in higher education institutions," Rev. Científica, vol. 1, no. 24, p. 41, Jun. 2016. https://doi.org/10.14483/10.14483/udistrital.jour.RC.2016.24.a4

[17] L. A. Obando, "Anatomía de los PRAE," Luna Azul, no. 33, pp. 178 193, Sep. 2011. https://doi.org/10.17151/luaz.2011.33.14

[18] B. A. Rengifo Rengifo, L. Quitiaquez Segura, and F. J. Mora Córdoba, "La educación ambiental una estrategia pedagógica que contribuye a la solución de la problemática ambiental en Colombia," 2012.

[19] L. Trif, "Training Models of Social Constructivism. Teaching Based on Developing A Scaffold," Procedia - Soc. Behav. Sci., vol. 180, pp. 978-983, 2015. https://doi.org/10.1016/j.sbspro.2015.02.184

[20] A. Vilches and D. Gil, Construyamos un futuro sostenible : diálogos de supervivencia. Cambridge University Press, 2003.

[21] R. Penwell, L. L. Cronin-Jones, M. Hakverdi, S. Cline, and C. Johnson, "Teacher perceptions regarding the status of Environmental Education in Latin American Elementary Schools," Am. Educ. Res. Assoc., 2002.

[22] L. G. Jaramillo-Echeverri and J. C. Aguirre-García, "La investigación escolar y la formación de formadores," Magis. Rev. Int. Investig. en Educ., vol. 8, no. 16, p. 169, Oct. 2015. https://doi.org/10.11144/Javeriana.m8-16.ieff

[23] H. González, "Los proyectos ambientales escolares en las instituciones educativas del municipio de El Bando Magdalena," 2016.

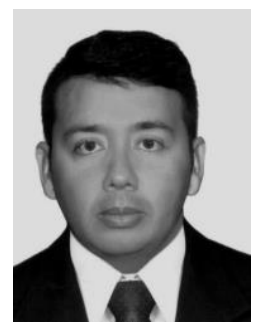

Christian Felipe Valderrama received the B.S. degree in environmental and sanitary engineering in 2008 from Univerisdad de la Salle, Bogotá, Colombia, and a master's degree in industrial hygiene from Universidad Autónoma de Occidente, Cali, Colombia in 2019. He is currently pursuing a $\mathrm{Ph} . \mathrm{D}$. degree in science and environmental technologies at Universidad de León, Spain.

Since 2012, he has been a part-time professor at Universidad Nacional Abierta y a Distancia, Neiva, Colombia, and as a public and private consultant in environmental management applying the circular economy models to his clients. He belongs to the research group COBIDES. His research interest includes environmental pollutants, environmental education and solid waste management.

ORCID: https://orcid.org/0000-0003-2260-5046

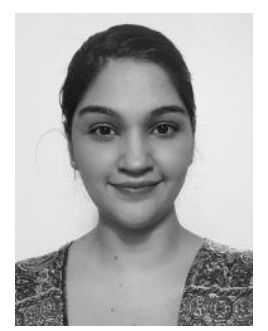

Olga Lucía Fierro holds a B.A. degree in English language teaching from Universidad Surcolombiana, Neiva, Colombia, in 2017, a specialization in university teaching from Universidad Cooperativa de Colombia, Bogotá, Colombia, and an M.A. degree in English from Universidad Surcolombiana, in 2019. She is currently pursuing an M.A. degree in education at Universidad Cooperativa de Colombia. She has worked as a part-time professor with the ELT department at Universidad Nacional Abierta y a Distancia since 2018. Her research interest includes the designing of strategies that promote and improve the teaching-learning processes at all levels.

ORCID: http://orcid.org/0000-0001-5496-1200 


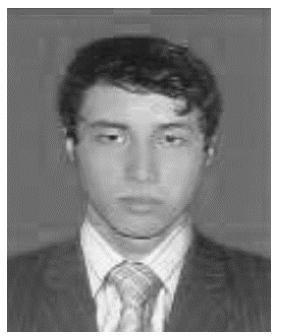

Juan David Ortiz received the B.S. degree in environmental engineering from Universidad Nacional Abierta y a Distancia, Neiva, Colombia, in 2019. From 2016 to 2019, he was a member from the hotbed of research Metamorfo. Mr. Ortiz received a scholarship from the Ministry of Agriculture to study his bachelor's degree.

ORCID: http://orcid.org/0000-0002-3506-435X

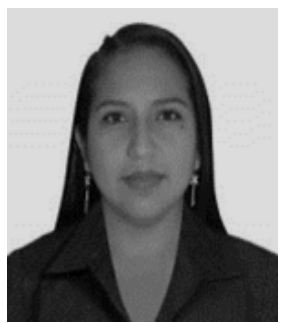

Maria Usa Peña received the B.S. degree in environmental engineering from Universidad Nacional Abierta y a Distancia, Colombia, in 2019. She was a member from the hotbed of research Metamorfo from 2016 to 2019.

ORCID: https://orcid.org/0000-00016892-0135 